DOI: http://dx.doi.org/10.4322/apa.2015.024

\title{
ANTARTICA'S NEW BUILDINGS: SEARCHING FOR MORE EFFICIENT CONSTRUCTIVE SYSTEMS
}

\author{
Cristina Engel de Alvarez*, Fernanda Mayumi Fukai, Marina Silva Tomé \& Paulo Sérgio de Paula Vargas \\ Laboratório de Planejamento e Projetos da Universidade Federal do Espírito Santo (LPP/UFES), \\ Av. Fernando Ferrari n 514, CEMUNI I sala 7, CEP 29075-910, Vitória, ES, Brazil \\ *e-mail: cristina.engel@ufes.br
}

\begin{abstract}
Taking into account the need for rebuilding the Comandante Ferraz Antarctic Station due to the destruction of its main building in February 2012, this research is aimed at identifying and analyzing the constructive techniques employed in reference to scientific stations, addressing potential replicability for new Brazilian buildings. The methodology adopted, in addition to the required literature review, established as timeframe for choosing referential buildings the maximum period of 10 years of construction. Six buildings were previously selected and analyzed according to the aspects of architecture and constructive systems. The information has been selected and systematized in the form of a summary table. The results pointed to recurring use of constructive systems based on metallic structures, designed in a modular way and protected by coatings isolating them from the direct action of the weather, with techniques developed in accordance with the logistical support available. Furthermore, the aerodynamic design of the buildings and the ground elevation were observed, as well as a marked concern for the use of proven efficient technologies without restricting aspects of innovation.
\end{abstract}

Keywords: Research Stations, Architecture, Constructive Systems, Sustainability

\section{Introduction}

The historic interest of Brazil in the Antarctic continent can be justified for the strategic importance, the physic proximity, the exceptional conditions for scientific research in many areas of de knowledge and the influence of meteorological and oceanographic phenomena of Antarctica in Brazilian territory (Marinha do Brasil, 2013). The latter led to the establishment of the Comandante Ferraz Antarctic Station (EACF) in 1984, set up in order to provide support for Antarctic program and develop scientific-oriented research in the region. In this context of occupying the region, the study of architectural solutions and constructive materials employed in the implementation of research stations, based on analysis of environmental constraints and other aspects influencing their applicability and performance, become a relevant research topic (Bargagli, 2008; Alvarez, 1993). Considering the need for rebuilding the EACF due to destruction of its main building caused by a fire in February 2012, this research aimed at identifying and analyzing the constructive techniques adopted in scientific stations addressing the potential replicability of solutions in the new Brazilian buildings.

\section{Materials and Methods}

The methodology used at the beginning of this work considered the need for carrying out a literature review and survey in the most relevant Antarctic Programs. As a time interval, the period maximum of 10 years of construction has been established, taking into account as additional criterion the availability of reliable information and duly highlighted as essential for the purposes of this research. From the first time interval, six referential buildings have been previously selected and analyzed according to their architectural aspects and their constructive systems. After confirming the reliability of the source, the information was selected and systematized in a form of summary table. 


\begin{tabular}{|c|c|c|}
\hline Stations & Features & Structure \\
\hline $\begin{array}{l}\text { Amundsen-Scoot South Pole Station } \\
\text { (United States) } \\
\text { Area: } 6.100 \mathrm{~m}^{2} \\
\text { Source: National Science Foundation (2013) }\end{array}$ & $\begin{array}{l}\text { - Two U-shaped buildings connected, } \\
\text { aligned symmetrically and } 3 \text { m high } \\
\text { from the ground; } \\
\text { - The aerodynamic shape allows } \\
\text { passage of the winds and to carry } \\
\text { the snow; } \\
\text { - Dimensions: } 124 \mathrm{~m} \times 45 \mathrm{~m} \times 24 \mathrm{~m} \text { in } \\
\text { height; } \\
\text { - Floors: basement (operational), } \\
\text { Piloted, floors } 1 \text { and } 2 \text { (housing, } \\
\text { food, recreation, administration, } \\
\text { laboratories and communication). }\end{array}$ & $\begin{array}{l}\text { - Structure in steel with } 36 \text { columns of } \\
15 \mathrm{~mm} \text { in height supported on metal } \\
\text { flat beams lattice placed on a bed } \\
\text { of highly compressed snow } 1.8 \mathrm{~m} \\
\text { thickness. } \\
\text { - Hydraulic lifting system } \\
\text { - Seals in panels composed of two } \\
\text { sheets of OSB with kernels of } \\
\text { expanded polystyrene (EPS). }\end{array}$ \\
\hline $\begin{array}{l}\text { Bharati Antarctic Research Station (India) } \\
\text { Area: } 2.400 \mathrm{~m}^{2} \\
\text { Source: BOF-Architecknen (2013) }\end{array}$ & $\begin{array}{l}\text { - Single parallelepiped-shaped } \\
\text { building lifted } 2 \mathrm{~m} \text { from the ground; } \\
\text { - Aerodynamic shape allows the } \\
\text { passage of the winds; } \\
\text { - Dimensions: } 50 \mathrm{~m} \times 30 \mathrm{~m} \times 12 \mathrm{~m} \text { in } \\
\text { height; } \\
\text { - Floors: upper (housing) and lower } \\
\text { (laboratories e operational). } \\
\text { - Note: the space between the } \\
\text { external casing and the internal } \\
\text { units creates an air pocket used to } \\
\text { regulate the temperature inside and } \\
\text { serve as access to maintenance and } \\
\text { emergency exit. }\end{array}$ & $\begin{array}{l}\text { - Structure in metal beams supported } \\
\text { on steel columns of } 2 \text { m height } \\
\text { associated with prefabricated } \\
\text { containers; } \\
\text { - Core with about } 130 \text { prefabricated } \\
\text { containers with built-in insulation } \\
\text { locks surrounded by a framework } \\
\text { made in steel coated by special } \\
\text { stainless steel with built-in thermal } \\
\text { insulation shaping air pocket } \\
\text { between them serving as a place } \\
\text { for power cables, access to } \\
\text { maintenance, thermal regulator and } \\
\text { as escape route. }\end{array}$ \\
\hline $\begin{array}{l}\text { Halley VI Research Station (United Kingdon) } \\
\text { Area: } 1.858 \mathrm{~m}^{2} \\
\text { Source: Hugh Broughton Architects (2013) }\end{array}$ & $\begin{array}{l}\text { - Independent modules arranged in } \\
\text { a linear way perpendicular to the } \\
\text { prevailing winds and lifted above the } \\
\text { ground. } \\
\text { - Aerodynamic shape allows passage } \\
\text { of the winds. } \\
\text { - Dimensions: peripheral modules = } \\
152 \mathrm{~m}^{2} \text {; and central modules = } \\
467 \mathrm{~m}^{2} \text {. }\end{array}$ & $\begin{array}{l}\text { - Steel structure serving as basis of } \\
\text { the floor and support for beams and } \\
\text { upper structure. } \\
\text { - Seals with glass fiber-reinforced } \\
\text { plastic (GRP) panels joined by a } \\
\text { silicon rubber joint. Internal isolation } \\
\text { consisted in closed polysocianurate } \\
\text { cell foam closed and encapsulated } \\
\text { inside the GRP panels. } \\
\text { - Selection of materials with minimum } \\
\text { impact was carefully considered in } \\
\text { every phase of the design. } \\
\text { - Standardized components: } \\
\text { maximizing the exchange and } \\
\text { reducing the number of pieces in } \\
\text { storage in the place. }\end{array}$ \\
\hline
\end{tabular}

Source: Broughton (2013); Berte (2013); International Polar Foundation (2013); Alfred Wegener Institute (2013); British Antarctic Survey (2013) and Bof Architekten (2013), Brooks, W \& Ferraro, J (2010) 
Chart I. Features and structure of the referential buildings

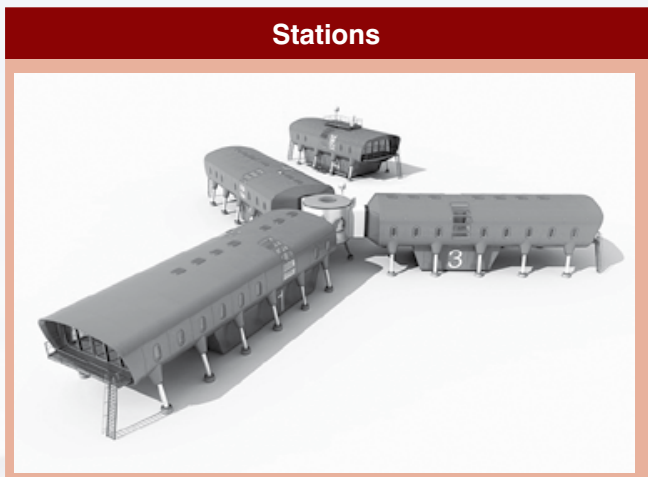

Juan Carlos I Antartic Research Station (Spain)

Area: $1280 \mathrm{~m}^{2}$

Source: Hugh Broughton Architects (2013)
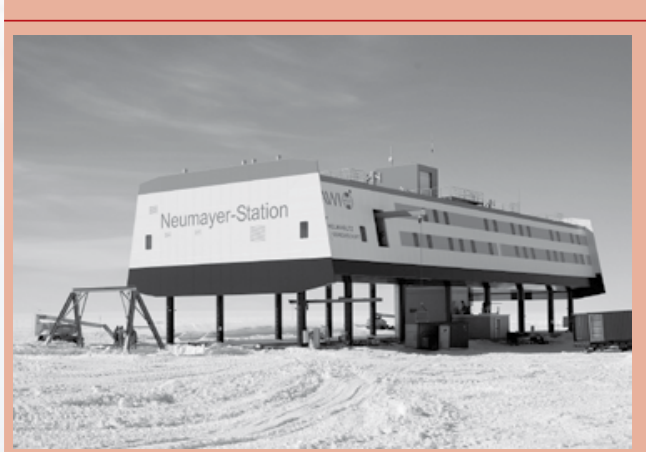

\section{Neumayer Station III (Germany)}

Area: $3.300 \mathrm{~m}^{2}$

Source: Alfred Wegener Institute (2013)

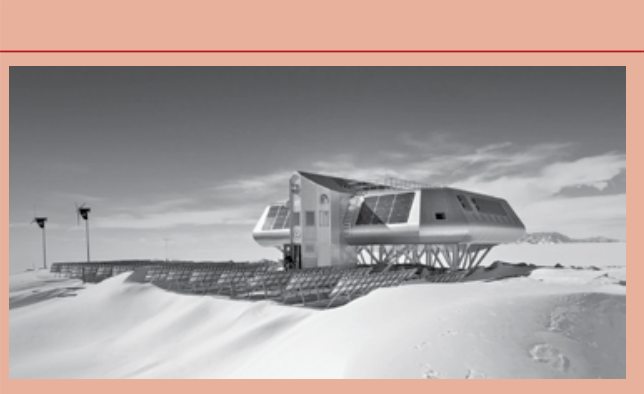

Princess Elisabeth Antarctica (Belgium)

Source: Internacional Polar Foundation (2013)

Area: $700 \mathrm{~m} 2$

\section{Features}

- Blocks interconnected to a central area and isolated units, lifted above the ground.

- The aerodynamic shape aids the passage of winds.

- Dimensions: 1,280m².

- Floors: 3 housings blocks around a central core and isolated units of laboratories and operational.

- Note: the station uses skylights and glass areas that maximizing the use of daylight, reducing the consumption of energy and allowing the researchers to keep visual contact with the surroundings.

- Single block mounted on a platform lifted $6 \mathrm{~m}$ above the ground.

- Aerodynamic shape aids the passage of winds.

- Dimensions of the support platform: $68 \mathrm{~m} \times 24 \mathrm{~m}$.

- Floors: basement (operational), piles, floors 1 and 2 (housings, social, laboratories)

- Note: the general shape of the building complies and protector involucres which harbors juxtaposed containers.

- Octognal single block;

- Aerodynamic shape aids the passage of winds.

- Dimensions: $400 \mathrm{~m}^{2}$ of living quarters and $1500 \mathrm{~m}^{2}$ for technical core.

- Floors: one.

- Note: the geometry of te station allows it to benefit from both solar passsive and active gain.

\section{Structure}

- Structure in monocoques modules rings of reinforced plastic fiber (single system of structure and envelopments);

- The tubular geometry eliminates the need for steel, which reduces the weight of the building (the weight of each ring is about 2.5 to 3 tons);

- Prefabricated concrete foundations and supported in moraines;

- Rings joints with aluminum strip covering.

- 32 hydraulic cylinders arranged in two groups that allows to lift the structures up to 1,2 meters.

- Total weight: 2,300 tons, distributed in 16 foundation slabs.

- Comprised of 99 containers arranged in two rows, on two levels, surrounded by a steel modular structure in trapezoidal prism shape coated with metallic panels, like a sandwich, filled with expanded polyurethane.

- Partitions in panels composed of magnesium and fiberglass reinforced plastic filled with mineral fiber.

- Structure of glued laminated timber, covered with panels with external stainless steel finish. Each side panel of $60 \mathrm{~cm}$ of thickness is formed by seven layers and minimizes heat loss through the walls;

- 34 supporting pillars firmly anchored at a depth of six meters on a granite base and tilted in various directions to withstand better the stresses caused by wind.

Source: Broughton (2013); Berte (2013); International Polar Foundation (2013); Alfred Wegener Institute (2013); British Antarctic Survey (2013) and Bof Architekten (2013), Brooks, W \& Ferraro, J (2010). 


\section{Results}

As a result, the obtained data was compiled and systematized in the chart below, which deals with the architectural and constructive aspects of the selected referential stations.

\section{Discussion and Conclusion}

From the analysis of the information the recurring use of metallic structure-based constructive systems could be noted (with the exception of the Juan Carlos I station, which is made in monocoque), designed in a modular way and protected by coatings that isolate them from the direct action of the weather. The design of the constructive system involves special concern with the logistical aspect and agile solutions for the transport and assembly of buildings. For the aspect related to technologies for isolation of the internal environment, the use of different techniques and materials that both address efficiency in keeping the internal heat and minimizing the effects of condensation of steam, were identified. Another relevant aspect refers to the aerodynamic design and elevation of the ground, both designed in order to increase the life cycle of the buildings, protecting them from the action of strong winds and using them to dissipate the snow accumulated under the buildings. It has been concluded that there is a marked concern about the use of technologies of proven efficiency that do not reduce any form of innovation, thereby establishing new levels of efficiency and durability in the Antarctic buildings.

\section{Acknowledgements}

This work is sponsored by the National Institute of Science and Technology Antarctic Environmental Research (INCTAPA) that receives scientific and financial support from the National Council for Research and Development (CNPq process: $n^{\circ}$ 574018/2008-5) and Carlos Chagas Research Support Foundation of the State of Rio de Janeiro (FAPERJ $n^{\circ}$ E-16/170.023/2008). The authors also acknowledge the support of the Brazilian Ministries of Science, Technology and Innovation (MCTI), of Environment (MMA) and InterMinistry Commission for Sea Resources (CIRM).

\section{References}

Alfred Wegener Institute (2013), Alfred Wegener Institute, Bremerhaven, Germany <http://www.awi.de/en/infrastructure/ stations/neumayer_station/> (access: 10 $0^{\text {th }}$ April 2013).

Alvarez, C. E. (1993). Residência de Verão. Revista Techne, 1(2):24 - 28.

Bargagli, R. (2008). Environmental contamination in Antarctic ecosystems. Science of The Total Environment. 400(1-3): 212-226

Bof Architekten (2013). Bof Architekten, Hamburg, Germany <http://bof-architekten.de/de/projekte/indische-polarstation/> (access: 10 $0^{\text {th }}$ April 2013).

British Antartic Survey (2013). British Antartic Survey, Cambridge, United Kingdom < http://www.antarctica.ac.uk/living_and working/research_stations/halley/> (access: 10 $0^{\text {th }}$ April 2013).

Brooks, W \& Ferraro, J (2010). Sustainable Design Strategies for the Modernization of the Amundsen-Scott South Pole Station, Honolulu, Hawaii, (2013) viewed 30 March 2013, <http://www.ferrarochoi.com/Publications/SUST\%20DESIGN\%20 STRATEGIES/SUSTDESIGN\%2001\%20Abstract.html> (access: 30th March 2013).

Hugh Broughton Architects (2013). Hugh Broughton Architects, London, United Kingdom < www.hbarchitects.co.uk/projects. php?project-list $=$ extreme\&id $=0>$ (access: $10^{\text {th }}$ April 2013).

International Polar Foundation (2013). International Polar Foundation, Bruxelles, Belgic <www.antarcticstation.org/station/ construction> (access: $20^{\text {th }}$ March 2013).

Marinha do Brasil (2013). Programa Antártico Brasileiro (PROANTAR), Rio de Janeiro, Brazil <www. mar.mil.br/secirm/proantar. htm $>$ (access: 16 ${ }^{\text {th }}$ March 2013). 